\title{
TOWARDS ALTERNATIVE STRATEGIES FOR SUSTAINABLE DEVELOPMENT IN AFRICA
}

\author{
C.T. EYONG ${ }^{1} \&$ I.I. FOY ${ }^{2}$ \\ ${ }^{1}$ Center for Development Research, Bonn, Germany. \\ ${ }^{2}$ Katholieke Universiteit Brussel, Belgium.
}

\begin{abstract}
African dynasties and empires enjoyed sustainable development prior to Western contact and conquest. This is fast eroding since the colonial era of rooting out all what is African by 'modernizing' Africa through the inculcation of Western ideologies and technologies. Bilateral and multilateral development cooperation for Africa has strongly favoured flawed strategies that put classical economic models at the forefront of Africa's development. This model favours the West's wasteful and highly polluting attitudes of overproduction and overconsumption. This paper exposes the unsustainability of this model and provides attributes for an alternative sustainable development strategy for Africa, which must win support and understanding amongst African leaders. A schematic at the end of this paper represents this gateway to Africa's ecological, economic and social resilience. A robust research agenda for regional case studies will generate data to ensure the revitalization of traditional coping strategies for the sustainable development of Africa.
\end{abstract}

Keywords: Africa, community sustainability indicators, development models, life support strategies, south-south NGO network, research, resilience self-sustenance, type III relationships.

\section{INTRODUCTION}

In this paper, we provide alternative strategies for sustainable development in Sub Saharan Africa (SSA). Focus is on countries located south of the Sahara and apart from West Sahara, 48 of the 53 independent states in Africa, including Sudan, belong to this region. In SSA, human development actually regressed in more than 50\% of the countries between 1990 and 2000, and the lives of its very poor people are getting worse. It is reported that the human development index of the region, by 2002 , stood at 0.465 ([1], p. 142). The percentage of people living on less than $\$ 1$ a day was about the same at the end of the 1990s $(47 \%)$ as at the start [2,3]. The number of poor people in the region increased with population growth, and in 2003 , over $81 \%$ of the countries in the low human development rank was from SSA ([4], p. 240). The sub region is blessed with enormous cultural, mineral and natural resources, but largely depends on foreign companies for their exploitation and transformation. Despite this richness, Africa has faced problems due to its inability to embark on a meaningful path to a level of well being deemed satisfactory for a sizable proportion of its population. Given the interconnectedness of the world, thanks to the fast evolving nature of science and technology, Western societies are increasingly flooded by Africans fleeing the sub region in an illusive search for a better life. The problems that plague Africa are an ongoing process, a social history of which each and every African is a part and parcel. By implication, African scholars need to focus their attention on strategies to 'study up' their societies and find sustainable solutions to contemporary problems of this continent. Lack of data or a distorted presentation of data on the sub region is a serious impediment, but not a reason for inaction. As academics from the sub region, we feel an urgent duty and call to incorporate all the ecological, socio-economic and political problems into an academic mainstream with a view to look for workable sustainable development strategies. This safely falls within the ambits of the call by post-modern anthropologists for a shift from the "exotic other' to the anthropology of 'ourselves' or the call to 'anthropologize' ourselves [5].

For decades, the development strategies for Africa were founded upon literature gathered and put together by 'prejudiced' anthropologists, who were never free from the influence of colonial 
administrators who funded such studies [6]. These high-handed studies, for the most part, favoured the total deletion of all that is African, and subsequent development interventions regarded African culture or way of life as 'development barriers' [7]. For instance, in cultural studies, ethnic or nationalist movements are represented as resulting from cultural interests generated by emotions with complexities of identity formation [8]. The 1980s and the late 1990s marked a turning point. With the increasing realization of the fundamental flaws of relegating African cultures in development interventions, it is hoped that Africans can have a chance to choose and own their development according to their way of life that is compatible with nature and respect for all generations. The aim of this paper is to review the answers to the following thematic questions; given that sustainable development strategies are based on what is already known about the region, can we think of a viable sustainability strategy if we rely on the existing details about SSA? Has there been sustainable development in the history of Africa? What went wrong and why? How can Africa embark on a path to sustainable development? While no easy answers to these questions exist, they leave many indifferent. In the following sections, we will explicate the key concepts.

\subsection{The concept of sustainable development revisited}

Scholarly works on development in Africa have often relegated the environmental factor, as scholarly discourses argue that her development is more about economic progress. No doubt, economists and accountants now sell in the continent like tea and coffee in the heart of winter in Western Europe. Since the environmental good is a public one, it is hard to think that anyone will cater to it. There is no ownership over an intangible good, let alone a public good. But sustainable development cannot be measured solely in economic terms. It must also include changes in the quality of life; so it is about change for the better. Equity, sustainability and justice should be pivotal in any such changes. It also means reaching out to poor people, and not only the rich, so that they meet their basic needs as indicated in the Millennium Development Goals [9]. Sound pro-poor policies and the right social safety nets would guarantee the transformation of these goals to gains in SSA. The reduction and elimination of poverty, inequality and unemployment can only yield fruits when there is a reign of peace within a society; not merely the absence of war or violence. Indicators, such as GDP, and human development indices, such as life expectancy, access to health, clean water and education, are used to measure human development. What, then, is sustainable development? Sustainable development is a fluid concept that came to the forefront late in the development discourse, especially in the work of L.R. Brown [10] and the Brundtlandt Report (1987), which defined it as 'development that meets the needs of the present generation without compromising the ability of future generations to meet theirs,' ([11], p. 8). Though influential, this definition is political and very vague, and industrialized countries have so far only paid lip service to it. It has been defined differently and can be defined in terms of indicators, or what it specifically seeks to measure ([12], p. 13). Sustainable development is a planned cultural, economic, social, environmental and political change for the better, which needs cooperation at all the levels by all the stakeholders, geared towards the well-being of the masses, for the masses and by the masses. It is a societal good and every social actor must get involved and stay engaged in its pursuit. It is long termed, fosters inter and intragenerational equity and does not foul the air, poison the water, disequilibrate forest ecosystems or pollute and degrade lands [13]. In this light, we argue here that sustainable development is not a reality in any society and that all societies are still developing either by scaling up or scaling down their production and consumption patterns. Sound sustainable development strategies for SSA must reflect its multi-ethnic and cultural diversity and a reign of peace. 


\section{BRIEF HISTORY OF AFRICA'S PAST AND PRESENT SUSTAINABILITY CHALLENGES}

Historical evidence points to the fact that former African kingdoms were great centres of trade, culture, tradition and politics, but most are largely failed states today. A historical review of some great empires such as that of Mali, Mwanemutapa, Songhai and the Swahili kingdoms reveals that pre-colonial Africa had a rich history, culture, economy, polity and governance structures [14]. Prior to European contact and conquest, Africa experienced a level of development that was at par with the West if not more advanced in some aspects. For instance, 'the Soninke people of the empire of Ghana are said to have enjoyed a world rich in culture and famous as a center of learning and trade during the middle ages, while most of the people of Europe suffered disease, fear, ignorance, and oppression' ([15], pp. 48-49). The Ghana Empire, the earliest known empire of Western Sudan, had a flourishing history and culture from about 750 until $1076 \mathrm{AD}$ and its legacy is still celebrated in the name of the present day Republic of Ghana. The empire represented a long-distance trade based on gold and salt. The king was the centre of political power and there was a cordial relationship between traditional religions and Islam. This 'Land of Gold', possessed sophisticated methods of administration and taxation, large armies and a monopoly over notoriously well-concealed gold mines. Islam was never fully embraced by the king of the Soninke people who founded Ghana, but he fostered good relations with Muslim traders. This cordiality later became a weak point, capitalized by the Europeans, to eventually rape and render the entire sub region unsustainable, in what was termed the colonizing mission that accompanied the inhumane era of slavery and slave trade [14].

The mistake of the colonial anthropologists and the missionaries in labelling Africans as 'primitive', 'savage', 'barbaric', 'tradition bound', 'lacking in self-governance' and so on marked the beginning of unsustainability in Africa, as Africans were denied the right to pursue the development path and the level they had attained prior to the arrival of the Europeans. Although Arab traders exerted pressure on Africans, popular discourse in Europe centred only on liberating Africa from Arab and African slave traders. The real intentions of colonialism, domination, oppression and acquisition of territories and natural resources, which destroyed well-established African civilizations, received no mention. The British and the French used the 'indirect' and the 'direct rule' systems of governance that were actually variants of despotism [16]. Direct rule denied rights to subjects on racial grounds, while indirect rule incorporated them into a 'customary' mode of rule, with state-appointed native authorities defining custom [17]. Today, the law of the state in Africa is European, while the law of the people is African. The French kept changing from direct to indirect administration, while apartheid, that emerged relatively later, was actually a generic form of the colonial state in Africa. These systems of administration were founded on the politics of divide and rule, which have now been perfected by successive African governments with the intention to oppress the masses rather than work for their collective good. In the different phases of colonization, the white man's burden of the need to 'civilize', 'develop' and 'protect the environment' in non-white countries consists above all to deprive these people of their resources and rights, if not taking full control of them. This decentralized despotism set the pace for the rape of Africa. At the time of flag independence, colonial powers sought puppet rulers who mortgaged the continent's resources and plunged it into the mess it finds itself today. Governance and conflict resolution in the region is an uphill task. Contemporary African rulers possess Western tastes and values, though they are African in blood and complexion. They fly their pregnant wives to the UK, the USA or Ireland for childbirth, so that these children can earn the nationality of these countries. The nationality crisis in SSA mostly finds its roots in its leaders, who view their countries as a natural plantation worth clearing down when it is time to harvest. They develop 'faulty policies just to attain programmatic objectives' while the masses, whose 
lives these policies should improve, suffer in deprivation [18]. Their exposure to Western education, greed, egoism and the lust for power shape these unsustainable attitudes and practices. The imprints of these actions are economically, socially and ecologically non-resilient societies [14].

\section{SUSTAINABLE DEVELOPMENT PROBLEMS IN SSA}

Colonialism and contemporary neo-colonialism, slavery and the unmastered modernization programmes and projects that are constantly and brutally forced on to SSA by the globalization process ([19], p. 26) continue to keep the region on its knees Some sustainable development problems of contemporary Africa include:

\subsection{Economic problems}

3.1.1 Market failure and unfavourable terms of trade

Between 1997 and 2002, African countries experienced negative terms of trade because of their high commodity dependence with a declining share in world trade. African raw materials are exported at very low prices coupled with trade barriers, but finished goods from the industrialized countries are imported at exorbitant prices. African exports recorded a dramatic fall from $3.7 \%$ in 1980 to $1.5 \%$ in 2002, while imports fell from 3.1\% to $1.4 \%$ respectively ([20], p. 3); and Africa loses $\$ 100$ million, two times what it gets as aid each year, due to dubious trade barriers imposed on her exports ([21], p. 183). Disturbingly, the terms of trade declined for SSA countries with worse debt ratios. In 2001, the price of coffee, which is the main export of some SSA countries, fell by $35 \%$. For instance, in Benin, Burkina Faso, Chad and Mali, cotton prices fell by 19\%; in Mozambique and the United Republic of Tanzania, cashew prices fell by 69\%; in Senegal, fish prices fell by $21 \%$; and in Zambia, copper prices fell by 13\% [20]. This tells us that the 'commodity trap' is already a 'poverty trap' [22] Hence, 'markets will not work for the poor where exclusion from educational opportunity or poor health restricts ability to generate income or raise productivity and wages' [23]. Subsidies to Western farmers through the Common Agricultural Policy (CAP) of the European Commission and the Food and Agricultural Policy (FAP) of the USA are other aspects. Cotton prices were lowered as much as $26 \%$ by US $\$ 4$ billion per year's worth of US cotton surpluses [24]. These depressed cotton prices encouraged dumping in developing countries and put farmers out of business, leading to calls for outright cuts in subsidies. For instance, cotton revenues constitute about $50 \%$ to $80 \%$ of the exports of Mali, Benin, Togo and Burkina Faso, and more than 9 million people in West Africa rely on cotton for their livelihood. What does the future hold for them, when in 2002 the US produced $36 \%$ of the world's cotton exports and subsidized its 30,000 farmers to the tune of $\$ 3.6$ billion? On its part, the EU produces $2.5 \%$ of the world's cotton and from 2000 to 2002 its support to its 100,000 farmers amounted to an average of 800 million euros per year [25]. Market failures and negative terms of trade, amidst a heavy debt burden, are impediments to improvements in SSA.

\subsubsection{Declining incomes and crushing poverty}

Shortly after independence, most African countries enjoyed an economic boom that was however short-lived. It was estimated that until 2002, 40 of the 44 SSA countries, with $93 \%$ of the region's population, grew too slowly [3]. The gross domestic product growth (GDP) in SSA slowed from 3.3\% in 2002 to $2.4 \%$ in 2003 [26]. SSA faces declining income, massive unemployment and crushing poverty. It is proven that, 20 out of the 53 countries with declining incomes are from SSA. Poverty is the resultant of material deprivation as well as social exclusion from every aspect of human life. Illiteracy, ill health, gender inequality, and environmental degradation are all aspects of being poor ([26], p. 2). Also, neglect of rural infrastructure as well as the massive drain to urban areas have led 
to the 'the urbanization of poverty'. While global poverty declined from $40 \%$ in 1981 to $21 \%$ in 2001 with prospects of falling to $15 \%$ in 2015 , there was an upward spiral of poverty in SSA from $41 \%$ in 1981 to $46 \%$ in 2001 [26]. The complex nature of poverty remains a major source of the complexity in understanding and finding sustainable solutions to the heavy debt burden of SSA.

\subsubsection{Heavy debt burden}

Every year, SSA pays $\$ 15$ billion in debt service for over $\$ 300$ billion worth of debts [27]. This is about four times as much money spent on health care and education in the region. While her debt service amounted to $3.8 \%$ of GDP in 2000, SSA countries spent $2.4 \%$ of their GDP on health. The past decade marked a period of 'negative net transfer' of $\$ 3.1$ billion. In 2001, SSA borrowed $\$ 11.4$ billion, but paid $\$ 14.5$ billion in debt service minus $\$ 9.8$ billion as principal repayment and $\$ 4.7$ billion as interest [27]. Despite an inability to repay debts, there is a dire need for more loans to finance domestic projects. Hence, the debt burden keeps mounting and future generations will live to pay debts, old debts. A common strategy has been to give away forest as debt payment, and today huge multinational companies are cutting down forests in Africa without paying high enough timber royalties. The EU is also letting its fishing boats to freely fish around the coast of West Africa, further depriving the poor and heavily indebted communities here. The 'aid fatigue of the 1990s', amidst mounting debts, pushed creditors to the discussion table on calls for debt forgiveness [28]. The unanimously adopted Heavily Indebted Poor Countries Initiative, under which the appalling debt situation in the poorest countries was to be made sustainable, is highly flawed and only helps prepare indebted countries to pay more debts. The reform packages from the IMF and the World Bank have all tended to be a mortal poison to many people in SSA. Future generations will live to pay debts owed by the unwise lending policies of creditors and recipient countries in SSA today.

\subsubsection{Capital flight}

Capital flight in SSA began shortly after independence and is increasing today due to prevailing military dictatorships and civil and ethnic wars. Africa greatly suffers from the flight of intellectuals; which is the migration of writers, scientists and experts to the wealthier nations due mostly to political witch-hunting at home. Intellectual capital flight is the migration of intellectual materials such as information, knowledge, experience and intellectual property that can be used to develop Africa. For example, most productive African musicians live and work in developed countries and cede copyrights of most African music to Western music companies. Since African music is created for the taste and consumption of Westerners, it is fast losing its African authenticity. The yearly losses amount to billions of dollars. Capital flight from 25 SSA countries in the period 1970-1996 totalled more than $\$ 193$ billion (in 1996 dollars exchange rates) and in countries like Angola, Cameroon, Congo-Zaïre, Côte d'Ivoire, Nigeria, and Zambia, private external assets accumulated via capital flight exceed the public external debt [14]. In SSA, the cumulative capital flight in 1996 amounted to $\$ 193$ billion or to $\$ 285$ billion, plus the imputed interest earnings on flight capital. Capital flight exceeds the stock of debt by $\$ 14.5$ billion - $\$ 106.5$ billion. Taking capital flight as a measure of private external assets, and calculating net external assets as private external assets minus public external debts, SSA thus appears to be a net creditor vis-à-vis the rest of the world ([29], pp. 5-6). These estimates cover only the reported data; the figures might be frightening if they pictured the actual outflows. After all, one can argue that the money is not African.

Since the 1980s, Africa lost more than a third of its professionals and about 70,000 highly qualified Africans leave Africa every year to live and work in developed countries [30]. On the other hand, SSA spends billions of dollars to train doctors and nurses who flee to work in the US and the UK, where 
nurses and doctors are selling like tea and coffee would sell in the heart of winter. It is estimated that SSA spends over 4 billion dollars yearly on technical assistance, including the cost of hiring 100,000 foreign experts to do jobs that could have been done by Africans ([30], p. 1).

3.1.5 High aid dependence and continuous reliance on colonial masters

Due to the volatile world prices on Africa's primary commodity exports amidst mounting debt stocks and increasing poverty, SSA has a high dependence on external aid inflows. Foreign direct investments inflows decreased in 2002 by $20.6 \%$ in the least developed countries of Africa, excluding Chad [22]. In the same year, more than a quarter of the net global aid flows went to SSA, which was equivalent to $32 \%$ of the region's gross capital formation [26]. Unfortunately, some countries depend on foreign aid for over $24 \%$ of their GDP [29]. Aid dependence leads to loss of identity, lack of participation in decision-making, diminishing sense of responsibility for one's own future, initiative in gaining that future and the accountability of governments to their populations for shaping policies leading toward it $[28,31]$.

After nearly 100 years of economic exploitation and political repression, Africans had, and are having, little or no say in the political decisions that govern their daily lives. This is agreeable since aid has always been accompanied by political decisions dictated by donors to serve their interest. Former colonial masters, with the intention of protecting the exploitation mechanisms and structures they created and left behind, will stop at nothing to pressurize African stooges to pursue faulty policies that safeguard their interests. Governance structures that were previously centred on kinship ties and on the recognized leadership of people, who care for the needs of the communities, are replaced by centralized states that cannot deliver the goods. The European Union (EU) and the Bretton Wood Institutions implicitly imply this in the imposition of good governance as loan conditionality. When we look at bilateral aid flows, we see that colonial powers prefer dealing with former colonies, which still maintain the master-servant relationship created during colonialism. Making matters worse, the colonial masters left without adequately training Africans to manage and maintain the economic and political infrastructure. English-speaking Africa seems to be better. The handpicked puppet rulers are merely mimicking, rather than maintaining, the infrastructure left behind for the benefit of the population.

\subsection{Social problems}

\subsubsection{High fertility}

Africa's population could soar by more than 1 billion over the next half-century, further straining the food and water supplies and the social services in already struggling areas. This will mean creating millions of jobs and improving health-care facilities and schools. By international standards, the fertility ceiling of 5.5 in countries like Côte d'Ivoire, Cameroon, Namibia and the Central African Republic is disturbingly too high ([32], p. 2). This young age dependency further worsens the economic situation and the population increase threatens the depleting natural resources in the region. As the number of people to be provided for grows, resources tend to reduce in relative terms thus making planning and implementation of development programmes difficult. Since population increase trails behind food production and economic growth in SSA, there is severe population pressure on the environment as people try to scratch a living from the soil ([33], pp. 23-34). However, wars, HIV/AIDS, accidents and other disasters are playing their part to check population growth in the region. Easy access to condoms and other contraceptives are Western-packaged population checks for SSA, which is yet to yield positive results. Population growth is fuelling rapid urbanization in SSA. 
3.2.2 Rapid urbanization

Presently, 37\% of Africans live in cities. The high fertility in SSA has engineered a massive ruralurban drain and African cities are a blend of traditional and Western cultures. A total of 187 million people live in the cities in SSA, making up 72\% of Africa's urban citizens, representing the world's largest proportion of urban residents living in slums [34]. The average urban growth in the region is 4\%, twice as high as that of Latin America and Asia. By 2030, it will rise to 53\%, the world's highest rate of urbanization in history, which means that Africa's urban population doubles every 14 years [33]. Because many people in Africa are unable to make a living in rural areas, they drift to towns with hopes of getting a job and having a better life, which hardly happens - this is referred to as the urban illusion. Hence, rural poverty is perceptibly an urban misery in SSA. Moral decline, malnutrition, high infant mortality and crime and drug abuse, especially among the youth is rife. Increased poverty has fuelled insecurity, vulnerability, displacement, HIV/AIDS, rapidly growing urban slums, lack of basic services, sub-standard housing, hazardous locations, mounting solid wastes, insecurity of tenure and social exclusion. Only $48 \%$ of urban households have a water connection, while in the slums only $19 \%$ enjoy this service; only $31 \%$ of urban households are connected to the sewerage system compared to only $7 \%$ in the informal settlements; just $54 \%$ of urban households have electricity in their homes in contrast to $20 \%$ in the slums [34]. $15.5 \%$ of urban households have telephone lines while only $3 \%$ of slum dwellers have this luxury. These statistics clearly signify an urban divide in Africa. Rapid urban growth is rather a curse than a blessing in SSA, since it makes the realization of political stability, social order and, of course, economic progress less likely [33].

\subsubsection{Little commitment to democracy: civil wars and ethnic strife}

The governance structure in SSA before colonization was founded on strong community and cultural roots. Constitutional governments ruled the members of ethnic groups, though laws were undocumented and no one had any formal education. Ever since the 'invention of Africa' violent conflicts became widespread in the continent. Accountability, institutions of democratic participation, public interests, local values, concerns and centralized managements in SSA neglect traditions. The wholesale conversion of public property by public officials into private goods is turning huge exporting companies into the biggest debtors. Poor management of state funds, coupled with embezzlements and capital flight are creating budget deficits, paving the way to external begging. Realizing just how much bad governance in Africa will cost Western nations, the latter imposed conditionalities on aid, which impinge on the sovereignty of recipient states. These conditionalities ranged from privatization, democratization, environmental protection, trade and other policy reforms. However, African countries are responding to these conditions by evolving paper policy reforms with little results on the ground to qualify for a loan. Given the complexity in what good governance really means, the European Commission supports country initiatives rather than imposing the one-size-fits-all approach of the World Bank and the IMF. This notwithstanding, there is little hope for any participatory democracy with the stalling of the third democratic wave. For instance, in Cameroon and Togo among others, one-party states have allowed elections, but end up permitting only limited opening for political competition. These 'limited' democracies suffer from shallow political participation; citizens have little trust in their governments and are thus disaffected from politics. While theorists postulate more education for democratic participation, many SSA countries lapsed back into authoritarian rule, with the dominance of single powerful parties or groups despite formal elections [3]. The ultimate crime is political disloyalty to the president. The belly-centred politics of a goat eating where it is tethered coerces everybody to the ruling party, thereby giving credence to the assertion that 'if you are not with the ruling party, then you are against it and there is no need to have an enemy in the house'. The objective reality is - ravaging ethnic conflicts where bullets and not ballots influence politics. Guns, bombs 
and tanks, not votes, seem to be the legitimate way of choosing leaders, especially in Rwanda, the Democratic Republic of Congo, Liberia, Somalia, Cote d'Ivoire and Sudan to name a few.

Another cause of conflict is what is known as 'ethnic democracies' in the region. Instead of every ethnic group uniting to fight their common enemy (the leaders who care less about the governed), these ethnic groups carry guns and fight against each other for the simple reason that 'you do not belong to the same ethnic group as me'. Over the past two decades, SSA hosted at least five conflicts or civil wars. War breeds the dangerous phenomenon of child soldiers. Thousands of children are in the war front; fighting for a cause they know little or nothing about. Sadly enough, these wars are being fought with weapons of mass destruction acquired from the developed countries as a loan, or are bought with state funds that should have been invested in the education and health sectors. For instance, Kenya was heavily indebted in 2001, but most of these debts were incurred in the form of weapons of mass destruction for use against Kenyan dissidents. Also loans were used to build 'torture chambers' that were exposed when former president Arap Moi was ousted from power in 2003. Political dissent, unemployment, poverty and despotism are all sources and causes of wars in SSA. Such an unstable atmosphere is a deterrent for foreign investment and assistance. In a climate of chaos, inter-ethnic mistrust, insecurity and violence, no amount of development aid can put a society on its path to sustainable development.

3.2.4 Contradictions and mutual distrust among the ruling elite

Enormous internal contradictions prevent the ruling elite in SSA from uniting and communicating with one voice. For example, while Libya and Zimbabwe hold a radical position within the African Union (AU) and New Economic Partnership for Africa's Development (NEPAD), Nigeria and South Africa take a liberal and pro-Western stance. NEPAD's peer review initiative is a good move towards good governance and accountability in Africa, but African leaders are reluctantly signing to it. These divisions are playing to the advantage of Westerners, especially the EU. Internal divisions and the weak bargaining powers of the African states give the advantage to the EU. Formerly, negotiations between the African, Caribbean and the Pacific countries and the EU involved everyone as a group. Today, the EU, being aware of the enormous power of the combined group, has now adopted a policy that splits African, Caribbean and Pacific countries. On the contrary, Latin American countries have understood the interest of the West and therefore unite in many aspects to defend their collective welfare.

\subsection{Ecological problems}

Poverty is the major cause of Africa's declining natural resources. Although too much hunting pressures are putting bush meat under siege in the forests and while rivers, oceans and streams are being over-fished, the continent illusively suffers from a low-protein intake. Also, self-sufficiency of food is a laughable luxury in some countries. Massive clearing of forests for farming and logging to meet the high demand for fuel wood and construction of infrastructure are causing deforestation and desertification in the region. For instance, about 350,000 ha of forests are being cut down annually in Cameroon. The outtake by local residents does not surpass the activities of foreign commercial loggers who clear down forests in very unsustainable ways to satisfy their profit motives. The Yaoundé Forest Declaration of 1999 committed participating governments to the protection of 12 million acres, cooperation across borders to control poaching and the bush meat trade, and the promotion of responsible forest management among logging companies. The 2004 summit in Congo Brazzaville saw the signing of TRIDOM - an agreement on transborder cooperation to help conserve 37 million acres of forest, including Dja, Odzala and Minkebe National Parks - the equivalent of 7.5\% of the entire Congo Basin. 
Logging companies in the region are now actively working on certification. Additionally, the U.S. government affirmed its commitment to the region through the $\$ 53$ million Congo Basin Forest Partnership, while the EU pledged $\$ 52$ million [35]. Parks are created but, without significant outside funding, end up as paper parks. Tropical forests help in carbon sequestration, but forest preservation deprives the local people of benefits and resources, while African debts and burden are growing. Also, overgrazing and overcropping put much stress on arable land. Water shortages, air pollution, malnutrition and environmental diseases are the mainstay. Hazards such as floods, draughts and invasion of pests, such as locusts, are worsening the bad food scarcity problem. Women and children walk long distances to fetch water and firewood. Not only do people in this region have to manage a deteriorating environment, but they also suffer from these conditions. Aggravating the environmental crisis in SSA are faulty government policies that lease longer forest concessions to foreign commercial loggers and charge lower exploitation fees [18]. The accelerated unsustainable exploitation of timber by foreign commercial loggers is putting the forest ecosystems under siege. Wetlands, which are gene reserves, are on the verge of disappearing. Land, air and water pollution are no less a problem in urban and rural areas, although no data exists.

\section{WHY ATTEMPTS AT TACKLING THESE PROBLEMS HAVE YIELDED LITTLE DIVIDENDS}

However, a great deal of efforts has been made by national and international partners to awake Africa from slumber and let it arise from sleep. These efforts have been bilateral as well as multilateral and regional as well as inter-regional. We argue here that it is a possibility that without slavery and slave trade, Western domination, oppression and rape of the sub region, Africa would have slowly but surely followed its path to sustainable development. Slavery took away the able-bodied men and women of the continent, who would have worked to build it at their pace, aspirations and capabilities. The weaker ones had to depend on the Westerners. Development cooperation with industrialized countries have so far dictated flawed strategies to solve Africa's problems, whose future remains bleak due to the following:

\subsection{Poor perception by Western countries of Africa and Africans}

The very image of Africa and Africans painted by colonial anthropologists and which imperialist Western media is perfecting today is that the latter are inferior, lack self-governance and are backward in every aspect of life. To many Westerners, SSA had no literacy and intellectualism and this is justified by the widely publicized notion of Africa as a continent of 'song and dance' [36]. Although SSA has a rich intellectual heritage, which is familiar to many Africans, Westerners still tend to believe that Africa has had only an oral, non-literate culture. Contrarily, recently discovered manuscripts dating to the 14th century show that Timbuktu (Mali) was a haven of high literacy, a religious and a cultural hub and at the commercial crossroads on the trans-Saharan caravan route [36]. This perception has made Africa a millhouse for economic experiments by the IMF and other development partners. One of the many examples is the late 1980 reforms to cut clientelism, rent-seeking and public expenditure; the IMF and World Bank urged African governments to withdraw from most of their activities. The outcome was disastrous; weak states incapable of carrying out their basic functions; a demoralized workforce; state spending shrank and civil servants sought to make up for lost salaries by moonlighting and corruption ([37], pp. 291-329). Without a sound understanding of the cultural context of countries and communities for which intervention measures have been designed, structural adjustment programmes, enhanced structural adjustment programmes, etc. all wrapped in the one sizefits-all development model of the IMF and the World Bank have been forced on the African ministers 
of finance and the governments [21]. The results are weak developmental states, mass misery and poverty, fast degrading lands, massive deforestation and species extinction.

The Western partners often think they know too well what SSA needs to foster its development, which is partly driven by their perception of Africans as inferior, less intelligent and lacking in capacities. Expatriates with little or no knowledge of the local needs and aspirations are sent as experts and consultants to work in Africa on fat salaries and per diems from the aid package meant for financing the implementation of development projects. These die-hard prejudices have built over centuries and engraved in the collective memory of the population of Western nations to the extent that they have become part of their communication systems. For example, the growing power of the mass media in shaping and manipulating African values and tastes, and the quest for greener pastures, political tolerance, better social systems, greed and egoism account for the massive brain drain, which bleeds dry the workforce, and a resultant non-resilience [6].

\subsection{Inconsistent theories and concepts guide Africa's development}

Without a proper diagnosis, cures have been prescribed with the help of inconsistent and noncontextual theories and concepts. Africa's underdevelopment stems from the fact that the scramble for Africa was partly driven by the search for raw materials for the growing industrial base in Europe. Hence, colonization remains the tool through which a development paradigm for Africa was developed. Since the publication of the first poverty report by the World Bank in 1948, poverty has been defined as living on less than $\$ 2$ a day and extreme poverty as living on less than $\$ 1$ a day. This flawed definition pushed development agents and specialists to think that Africa needs economic growth in order to 'catch up' with the societies in the West ([2], pp. 31-33). Guided by modernist ideas, the intention is to let the continent move from tradition to modernity [7]. Such an evolutionary thinking is being propagated by newly emerging global financial institutions like the IMF and the World Bank, whose reform packages and loan conditionalities have ended up in a major tragedy. For instance, the structural adjustment programmes impoverish Africans who must meet their debt servicing requirements. Western donors have often favoured the transfer of technologies to SSA that is developed without taking the culture of the people into consideration. This technology transfer has underpinnings in SSA today; vast areas of forests are being transformed into deserts, arable land is fast degrading because of abusive and inappropriate use of fertilizers, rivers are being polluted with industrial effluents and biodiversity is lost. These are silent emergencies that SSA has to deal with as well as the loud emergency of global warming, though it contributes about 'two percent of global $\mathrm{CO}_{2}$ emissions' [38]. Polluting countries morally owe ecological debts to Africa.

Calls for privatization (global sell-off) and globalization are mere vehicles for transporting Western capitalist culture of overproduction and overconsumption, which generates more waste and pollutes most. Agreeably, these attitudes increase the GDP or the gross national product (GNP) of a country, but these neither ensure gross national happiness nor ensure that future generations can use the same resource base to meet their own development needs. There is ample evidence that the more affluent a society becomes, the more waste and environmental health hazards populations have to face and China is a good example [21]. The development model adopted for Africa is a photocopy of what the Western world used. This Economic Growth Model rests on the idea that the higher the GDP, the more economically well off that country is. A high growth as an indicator for successful economic governance means more pressure on the natural environment to an extent that its self-regenerative capacity is surpassed. Such a 'cowboy economics', characterized by the ruthless 'extraction of resources from the earth as if there were no limits and boundaries', fuels economic growth in the short term. More is taken out of the system, which cannot replenish itself. This system quickly comes to its limits making 
resources availability in the long term more of a joke. It does not reflect intergenerational equity and justice that is key to sustainability. Thanks to this classical economics idea, African countries today are recording stagnant economic growth rates of below $6 \%$. The question is at what expense? This growth means more production and consumption of goods and services, accompanied by heavy waste production and the plundering of the rich resources base. Yet longer-term economic and social development prospects remain bleak. Take the case of Botswana with a decadal GDP growth rate of $11.69 \%$, where per-capita income is US $\$ 3,056$, yet $47 \%$ of the population live below the national poverty line and the income of the poorest $20 \%$ of the population is 15 times less than that of the richest 20\% population [39]. The unsustainability of the Economic Growth Model represented below makes SSA unable to withstand external shocks (Fig. 1).

\subsection{Social erosion of traditional knowledge systems}

In today's world, knowledge is a factor of production and an economic asset, and where Africa stands today in relation to its knowledge resources is a multi-billion dollar question. It is no secret that Africa's mostly undocumented traditional knowledge systems are fast dying out. A range of internal factors like poverty [36,6], rigid and discriminatory access and application of knowledge, decline in the practitioner base, lack of codification, erosion of institutions that traditionally helped in the socialization of tacit knowledge and many others play a great role. However, these have been fuelled by colonialism, commercialization, globalization and modernization, which have granted cheap, if not free, access to the rich European researchers. These greedy Westerners now own copyrights and patents for merely repackaging the knowledge base, denying Africans access to their wealth of knowledge. In the ongoing debates, developing countries are known to be losers, yet they are endowed with abundant talent in music, medicine, software, textile designs and plant cultivation and conservation [40]. The revitalization of these knowledge systems has been a major challenge facing

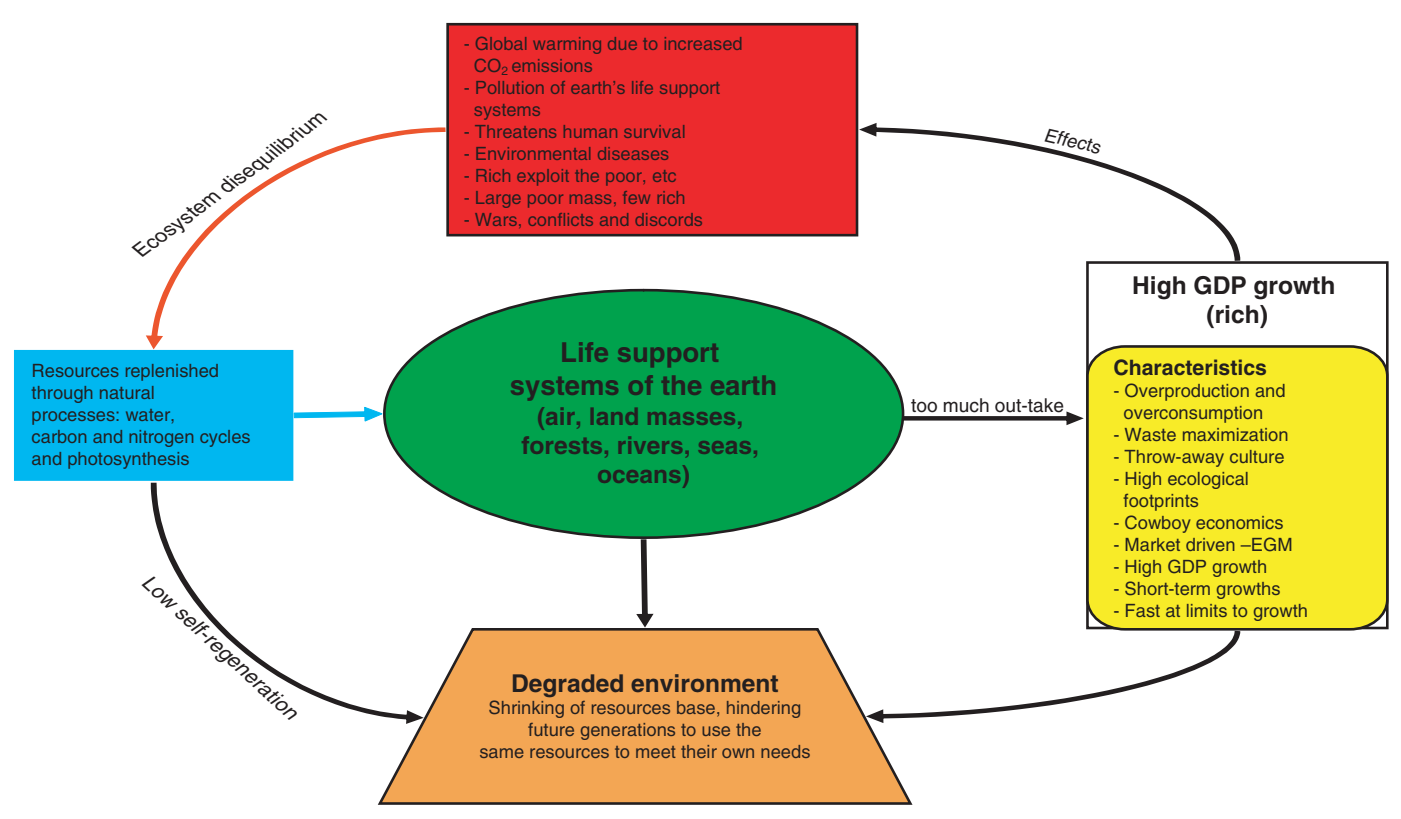

Figure 1: Diagrammatic representation of the unsustainability in the economic growth model. 
African governments, which are largely incompetent, ignorant or unwilling. Prior to the Monterrey Conference of March 2002, the 'type I' relationships that guided the development cooperation made money available to African governments and the latter did little to effectively use the money on development projects. The liberalization of socio-political life in the early 1990s saw the springing up of NGOs, which are instruments of people's participation giving hopes of a better future. The Monterrey Consensus identified the 'type II' relationships, enabling the southern NGOs to network with Western governments and make social development a reality in Africa. Today governments are back-passing their obligations to these NGOs, which also face serious challenges of accountability, access to new and reliable information systems, networking and poor financial environments. In southwest Cameroon for instance, new indigenous but weak secular NGOs have predominated since the enactment of the 19 December 1990 Liberty Laws, but perceptions of their capacity and credibility remain doubtful. Pockets of NGOs operate in the same area, on the same population and with similar objectives and action plans. They take advantage of the absence of a clear NGO regulatory framework, as well as little or no national funding and increasingly depend on foreign governments and Western NGOs for support.

\subsection{Inadequate knowledge of the development problem}

Many development projects have been carried out in Africa with very low success rates [28] because they were planned and implemented on the basis of poorly developed knowledge and information systems. The tendency has always been to use economists to plan, manage and evaluate the projects. Economists use criteria like the GNP or the per-capita income. When these increase, the erroneous conclusion is that the project is successful and should be maintained. Contrarily, these are totals and averages, which tell us little or nothing about the way income is distributed in the society, the exact picture of the standards of living and a lot more. As if this is not enough, baseline studies have often been carried out in selected countries in a bid to look for solutions to the problems of the wider sub region. While the sampling technique is a good academic tool, in the case of eradicating poverty in Africa, generalization may not reflect the relativity of communities and regions. For instance, one community may require access/farm-to-market roads while another may require the assistance of agricultural extension workers; so providing both to all communities is already a wasteful and an insensitive venture. Traditional knowledge systems, though discriminatory, provided life security that enabled Africans cope with their environment. Given that free thinking breeds critique, which is not good for the preserve of a government in power, African leaders have put all the communication channels at their beck and call. The degree of information and knowledge hoarding also determines the level of democracy in a society. Lack of a research culture is often hidden in the conception of poverty. The outcome is lack of data and insufficient knowledge on the development problems. This has and is making development partners very reluctant to invest in Africa. The absence of detailed regional and community-level studies means that the knowledge and the information available for action is insufficient - a major impediment, and disastrous.

\subsection{Lack of concrete action to implement development agendas}

A disillusioned activist may think Africa is unable to achieve a level of well-being deemed satisfactory for a majority of its citizens because very little is known of its problems. Many international fora organized under the auspices of the United Nations have discussed Africa's problems and formulated action plans for their redress. However, this too much talking has been accompanied by very limited 
concrete action. Industrialized countries are not putting their money where their mouth is. When Africa needed money, instead they gave lectures and pledges. For instance, world leaders agreed in 1972 to devote $0.7 \%$ of their GDP to finance development projects in the poor countries in a bid to fight global poverty and ignorance. So far, the level of commitment is only about $0.33 \%$. Countries like Denmark, Norway, Sweden, the Netherlands and Luxembourg are applauded for hitting or surpassing the $0.7 \%$ GDP target. On the other hand, we see double standards, as most of the economic capital flight from SSA is banked in Luxembourg and in Swiss banks where anonymity is guaranteed to all clients. Also, since donors consider first their interests and not those of the recipients, it is most plausible that development aid is driven by political interest rather than need, which will never allow a disadvantaged Africa effectively attain sustainable development.

Enthusiasts, including President Thabo Mbeki of South Africa, general Obassanjo of Nigeria and a host of others including Western leaders have been hailing the African Union (AU) and the New Economic Partnership for Africa's Development (NEPAD) as the panacea for Africa's development. The reality is that there is much reluctance to finance their operation. At Monterrey, the international community pledged only one-tenth of NEPAD's operational budget presented to them. African governments have been reluctant or unable to finance the cash-trapped AU with its over 17 affiliate institutions. Member states were charged \$55 million and other arrears in order to facilitate the transformation of the Organization of African Unity (OAU) to the AU, but only a few could pay up [41]. Libya bailed out 11 poor and heavily indebted African countries, which is proof that Libya is deeply committed to concrete action to strengthen the AU and reduce its dependence on external donors.

At the county or regional levels, politicians have often acted like birds without feathers. In the 1970s, local communities in Cameroon used to allocate a day for general cleaning of their surroundings and this was under a village-appointed supervisory committee. These self-reliant community efforts started eroding, as rogue politicians during election campaigns promised to build roads, provide pipeborne water and electricity, and even clean up towns, villages and cities. They always ask communities to make a list of all their needs, for them to take to Yaoundé. To prove their worth, some provide drinks and food to buy votes knowing full well that each vote is a potential feather. On the election day, if they are elected, which means they have had enough feathers, they fly and never come back to the people whom they had promised to provide for if voted into office. Their next return is when they come to campaign for re-election and so the line of lies and deceptions continues. This wait-for-the-politician attitude has eroded the community initiative, as local people now think 'our son in government' will come to clean their community. Move around the towns and big cities such as Douala, Bafoussam, Yaoundé and others, especially in areas inhabited by the poorest segments of the population, and you will be shocked by the odour, piles and unattractiveness of the waste abandoned on the roadsides. It is uncertain why disgruntled citizens cannot hold their politicians to be accountable to them in Cameroon as in other African countries.

\section{POSSIBLE STRATEGIES FOR SUSTAINABLE DEVELOPMENT IN SSA}

In this section, we argue strongly that despite these failed strategies, Africa has a window of opportunities to move ahead, if its leaders and people engage in practical strategies for her sustainable development, some of which include:

\subsection{Overcoming Western prejudices and improving Africa's poor image}

The die-hard prejudices in the Western world that are hampering the efforts at a committed international support for the sustainable development of Africa, requires an internal building and an 
external marketing of Africa's image. This cannot be effective if there is no attempt by the Africans, the ruling elite and the oppressed masses alike, to overcome their internal contradictions using effective dialogue, communication and negotiations on a horizontal basis to give peace a chance. The case in Togo concerning the manipulation of the Togolese constitution left many calling on the country's colonial master - France - to intervene. Since it was not inimical to the interest of France, there continued to be reluctance on the part of France to help the country out of the hands of dubious politicians. However, the member states of the Economic Community of West African States should not heed to the obstacles presented by France. Central Africa also needs to form a meaningful grouping not only for trade, but also on political and cultural grounds. The ridiculous trade barriers existing between African states soil her image and frighten investors.

Also, given that the international community has a vital role to play in Africa's sustainable development drive, permanent dialogue, communication and negotiation with the developed world as a united continent is essential if Africa is to succeed in accessing its share of the world's resources for financing its sustainable development efforts. Conservation efforts made by Africans over generations have deprived the poor who require compensation from the Western polluters as acknowledgement of their great sacrifice. It is no begging matter. SSA needs to be seen as the continent of a new sustainable development paradigm, which needs to integrate the forgotten or neglected impulses such as social cohesion and solidarity. Reviving traditional knowledge systems that provide life-security without discriminatory relations is vital. That is, moving towards a knowledge society, where knowledge is free and there is room for critical thought and free enquiry. People of a society should have control over the knowledge resources, knowledge products and knowledge processes (knowledge creation, knowledge sharing, knowledge application and enabling the environment) to be able to sell a good image abroad. African intellectuals as well as diplomats should play a greater role in building and marketing Africa's image abroad through their works and display of real commitment to the African course. Africans also need to critically explore their behaviours, attitudes and actions. It is important to establish avenues and mechanisms for sharing sensitivities, resources, research findings, discoveries, information and experiences on SUSTAINABLE DEVELOPMENT issues. These require active and committed involvement of all stakeholders who think Africa and act as Africans. The region has human resources that must be given the opportunity and support at all levels.

\subsection{A crosscutting strategy is that of education for sustainable development}

International policy documents like the Dakar framework on 'Education in Africa' urge member states to ensure that the learning needs of all young people and adults are met through equitable access to appropriate learning and life skills programmes [42]. The Ubuntu Declaration on 'Education, Science and Technology for Sustainable Development' identifies a global need to integrate a sustainable development focus into the curriculum at every level of education [43]. The declaration emphasizes curriculum development; North-South networking; strategic educational planning and policy-making; and capacity building in scientific research and learning. All these are warning signals that the development relevance of education in the region is highly questionable. Multi and interdisciplinarity should be central in every aspect of curriculum development and delivery. There is a need for learning for work, citizenship and sustainability for all sexes and genuine commitments to assure equity for all ethnic groups. This will reduce the problems of early childbirth, overpopulation, intellectual capital flight and lack of participation. A great advantage is in environmental awareness and capacity building for NGOs, consumer groups, industry, local governments and others. In Uganda, a national formal education environmental strategy and action plan is being integrated into 
the national curriculum. The plan involves NGOs, government offices, civil society and grassroots communities in practising better environmental management. Media awareness campaigns and environmental mass mobilization programmes should cover topical issues including soil conservation, agroforestry, wetland management and waste management. African countries should carefully and skillfully adapt these propositions to suit their local situations.

\subsection{Alternative/sustainable development model}

Alternatively, we think SSA can move from its current state of underdevelopment to sustainable development by adapting policies, programmes and projects, which ensure that the resource base is not depleted. That is, the Economic Growth Model, which has championed the development agenda imposed by Westerners and which perceptibly destroys the life support system of the earth (land, air and water bodies) should be avoided. It is glaring to any casual observer that the problem of overconsumption is common with the richest $10 \%$ and, with the absence of a middle-income class, the concept of 'spaceship ecology', which advocates that resource users extract resources considering the fact that the earth is a limiting reservoir - a spaceship where minimization of consumption should substitute maximization [44, 45], is still a joke. The wise use of resources ensures their equitable long-term availability for both present and future economic activities and avoids new poverty. Here, markets work for people and human resource policies do not see people as a means to an end but rather as an end in themselves. The emergence of a middle class ensures moderate consumption and production patterns. This alternative model is a development path that does not destroy the life support system of the earth. The key to this path is crosscutting and broadbased policies that guarantee inter and intragenerational equity for all sexes, social acceptability, improved quality of life for the masses and their full participation in development policies, programmes and projects, which should begin from the inception to the implementation phases. This path is known as Sustainable [Development Economic] Growth Model (Fig. 2). The simple difference with any other model as far as Africa is concerned is that it does not adhere entirely on the high rates of accumulation and industrialization as others argue [37]. It calls for modesty and equity.

The hurdle ahead is whether African politicians can adopt this model given that no election can be won on a platform of reduced lifestyle for the rich in Africa. Also, most of the people who are responsible for the development decisions of their respective countries are very unfamiliar with the concept of sustainable development. Their continuous maintenance in such positions without retraining on the dynamics of this new development path will in no instance be beneficial to any African country. As a remedy, the Human Ecology Department of the Free University of Brussels is training youth and endowing them with sufficient skills and insights necessary to transform the national sustainable development programme from an agenda to action. They do implement, plan, design and assess development projects on any scale. Given that their numbers are still very small, they should be employed to work with existing staff who are not beyond the retirement age. This requires substantial investments in capacity building and ensuring the effective use of existing human and institutional capacity through sound crosscutting policies and strategies. The African ruling elite should recognize that Africa's economic salvation cannot solely be guaranteed by the developed countries and donor funds. Continuous begging and aid dependence are not sustainable solutions to the problems of Africa. This attitude has engendered bad policies and turned Africans into human photocopying machines, uncritically copying and implementing Western development models and life styles that are inappropriate in the African context. Youth must work hard to change their current attitudes or perish. 


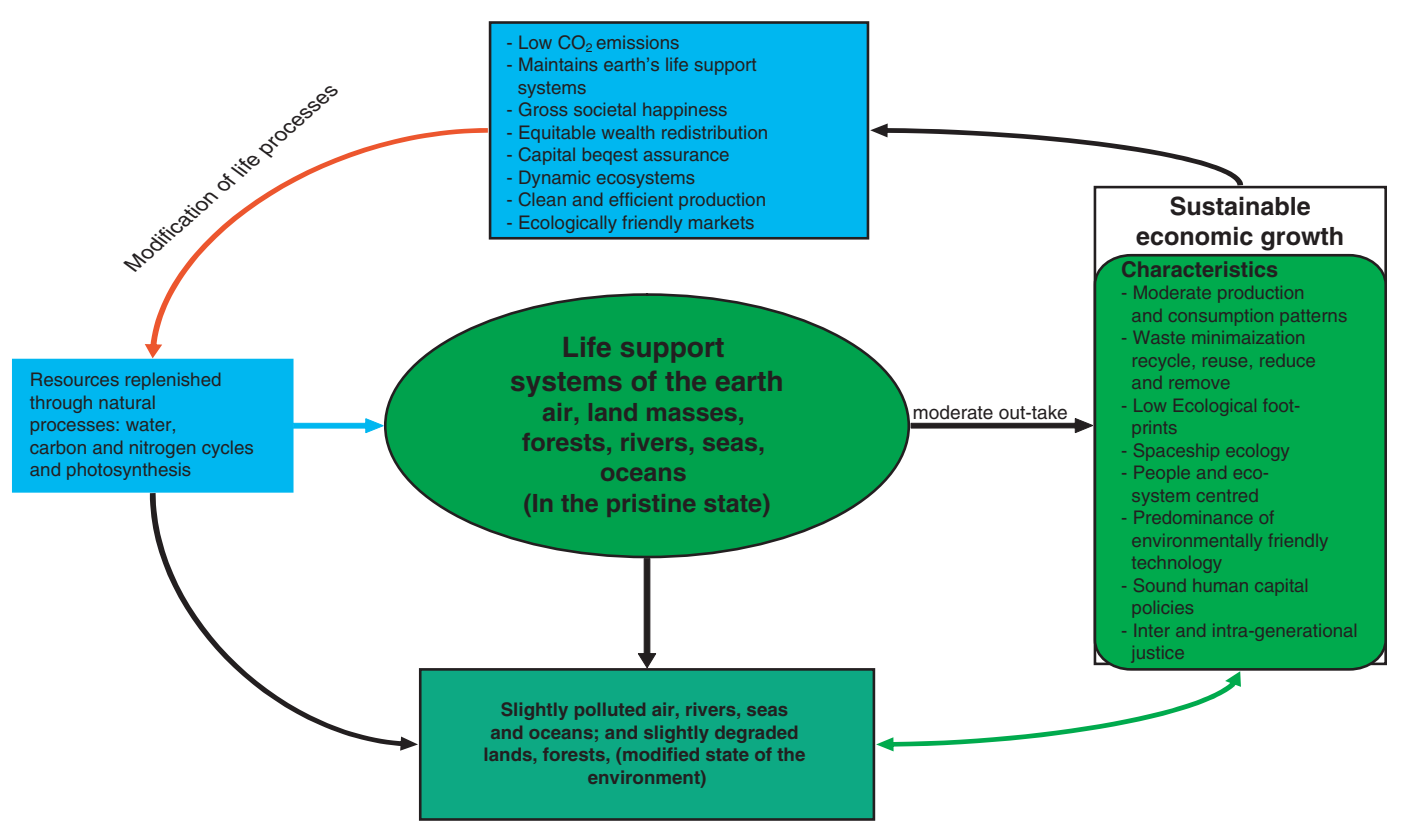

Figure 2: Diagrammatic representation of the economic growth path to sustainable development in SSA.

5.4 Concrete action-driven development agenda at the local, national and global levels

There has been sufficient debates and knowledge on Africa's challenges. It is time to match words with action. At the local level, community members should be empowered with functional skills through value-creative education to effectively contribute their own quota to the sustainable development of their areas. Local people need to understand that governments are unable to unilaterally run development projects, and so need support from them. This means the politics of lies-for-votes should be abandoned for more sincerity. This breeds trust and cooperation that is necessary for any sustainable development venture. At the national level, governments have to transform their poverty reduction strategies from paper policies to community-based action projects. The support for small and medium enterprises through micro credits and soft loans should be encouraged. The international community has its own role to play. Africa needs money to render lectures practical. Libya's bailing out of 11 poor and heavily indebted African states with the charged fee of $\$ 55$ million and other arrears for the transformation of the OAU to the AU is highly applauded [41]. Other African countries should effectively mobilize their domestic resources to be able to make their contributions to the AU and NEPAD, which promise much to the sustainable development of the continent. Although no legal international framework to ensure international commitment to financing development in SSA exists, ethics should guide political will. Development cooperation should benefit poor countries instead of the rich. Official German government Internet sources state that in 2003, bilateral trade between the Federal Republic of Germany and the Republic of Cameroon amounted to some 131 million euros, with a trade surplus of about 16.4 million euros in Germany's favour. The industrialized countries should follow the good example of countries like Denmark, Norway, Sweden, the Netherlands and Luxembourg that have hit or surpassed the 0.7\% GDP target. Genuine commitment 
by the rich countries to keep to their promises is needed if the current levels of ODA have to be stepped up as recommended by the Monterrey Consensus. The realization that unsustainability in Africa is affecting the sustainability of the West should drive concrete actions in the richest countries to make the current brain drain instead benefit the region through an organized way of labour exportation.

\subsection{Revitalizing traditional coping mechanisms}

We shall explain this in relation to biodiversity conservation especially in the management of the natural resources and the ecosystem. Conservation initiatives in African hot spots always end up creating new poverty and mass misery amongst local communities who become 'conservation refugees' [46]. Displaced villagers know that the ownership of their source of livelihood (forest) has changed hands and so there is 'no need to protect what belongs to the government' since 'government's property is no man's property'. Forced relocation does not take into consideration the sustainability aspects of traditional knowledge systems since Westerners think and see local people as 'being in the way of conservation'. Yet, ordinary Africans have coping mechanisms that have enabled them survive adversity in their surroundings and have preserved them for long. Thanks to indigenous knowledge of medicinal plants, a total of 36 medicinal plants discovered in the Korup National Park in Cameroon are new to science, and the medicinal vine, Ancistrocladus korupensis shown (in vitro) to be active against the HIV/AIDS virus was discovered in the area. This is suggestive of a link between 'traditional' and 'modern' medicine. The National Park strategy is widespread and forced relocation in the area does not acknowledge the contribution of local knowledge and the use of medicinal plants. Also, traditional healers are being prevented from harvesting medicinal plants, forcing the local people to make use of modern health-care facilities, which kills indigenous healing practices and hence results in unsustainability. Other important coping strategies for biodiversity conservation include: sustainable local hunting habits, sacred forests, cultivation habits, local control of illegal exploiters, food taboos and the knowledge of the forest and its resources [6].

The success of revitalization depends on a committed process of social reengineering of traditional institutions of governance that thrives best on a community-level knowledge management with equitable systems of access and control over knowledge production, sharing and application. In this process, global knowledge systems should be used to generate local knowledge. Patenting traditional knowledge systems can effectively work as a sustainable development tool in SSA only when fashioned within the framework of the World Intellectual Property Organization initiative. The so-called 'minimum standards' within the TRIPS framework has to be respected to enable local people get benefits for what they have developed and preserved for centuries. We expect the creativity and innovation of grassroots organizations in finding solutions on a dynamic basis. As development catalysts, they have to be knowledge based and knowledge driven. Given that sustainable development is a learning process, the starting point is from what people already know. The NGO education for sustainable development should be more about learning and teaching and not only teaching as has been the case. Although globalization, market economy, rapid technological changes and the digital divide are hindrances, they provide opportunities too. For instance, if the Internet is properly harnessed, it can facilitate a large-scale dissemination of indigenous ideas, mobilization of resources and collaboration among communities, organizations and networks. The NGOs are good intermediaries, channelling the views and preferences of affected persons to the executing agencies. To this end, we recommend southern NGOs to network by partnering with one another to look for better local solutions rather than only chasing foreign aid that is yet to bring desired outcomes. This is what we call 'type III relationships'. 
5.6 Need for detailed community/regional studies

A robust research agenda for community/regional studies is a necessary condition for a meaningful path to sustainable development to enable the Africans and the development partners to fully examine the realities and the aspirations of the ordinary Africans. Instead of relying on the much-distorted picture of African history portrayed in colonial literature [6], it is recommended that interdisciplinary research teams headed by African anthropologists should conduct extensive fieldwork. The fieldwork should fall within the context of current theoretical debates and clearly identify what went wrong during the colonial times. Instead of merely being research objects, committed African social anthropologists should help to create a positive rapport in the field and generate accurate data for retracing the African past. Anthropology is recommended because it provides a powerful portion in the curing of some of the development malaises of contemporary society [47]. It is an interdisciplinary science and the least dogmatic of all the sciences. Drawing lessons from an analysis of the personal accounts of six anthropologists, all trained in the tradition of social anthropology and working in a variety of different social, economic and environmental settings [48], this method has been regarded to be more beneficial. It goes without saying that human ecology can champion the research agenda to find a safe path to sustainable development in Africa given that anthropology has a firm basis of human ecology, especially in the dimension of man and the environment. Our recommendation in this light supports the fact that development projects in Africa are doomed to failure if anthropologists are not actively involved in the planning, evaluation and supervision of these projects, because local people are likely to resent projects that cause a serious change in their lives (for details and examples, see [49]).

These studies should adequately examine the functions of what we call Life Support Strategies (LSS) such as reciprocity, obligation and levelling in communities because they manifest the true African culture. If we agree with the assertion that culture fashions development [6], then it is worthwhile to retrace important African cultural traits subdued by Western colonialism. For instance, Westerners have often misinterpreted reciprocity, obligation and levelling as 'the anti-thesis to rationality' [7]. We shall explain each of these concepts with an example. For instance in a typical Cameroonian community, death is seen as a common problem. At such an event, sympathizers from far distances do not need an invitation to come and pay their last respect to the dead or to mourn with the bereaved. Going to the farm or to work when there is a corpse lying in the village is regarded as deviant, though it is economically unwise not to work for a while given that one needs to eat every day. Sympathizers come with food and drinks during celebrations to see off the ghost on its way to the spirit realm. They tell stories, sing and dance to appease the bereaved. When others are confronted with death, the same is reciprocated, representing an intragenerational contract for sustainability on an ethical basis to promote social solidarity and cohesion. In the West, handling of the dead is an individual matter where money plays a key role. There is little sustainability because money cannot buy cooperation at all levels to solve common problems [6].

It is an obligation for parents to socialize their young into the values of the community and to take responsibility for their actions. If a child turns out to be a prostitute, a thief or a killer, or has HIV/AIDS, or when two children from different parents fight, the latter are blamed. So we see a sort of intergenerational contract that seems to reduce disease, crime and deviant behaviours. Evolved societies interpret such attributes as interfering with the human rights of children and make the avoidance of this interference a loan conditionality. The outcomes are: increased incidence of sexually transmitted infections, killings or child prostitution. When families lose their socialization function delinquency rises and social bonds weaken, which is not good for the sustainability of society. In the same light, it is not uncommon for true Africans to refer to anyone they meet as brother, sister, father, mother, uncle or aunt, as the case may be, even if they are not related by blood or marriage. Witchcraft accusations, sorcery and magic are the most widely used levelling mechanisms. 
Individual achievements are in most cases associated with mystical powers. So to avoid expressing individualistic tendencies that invite witchcraft accusations, people tend to work for the survival of the group. This has also been reported amongst fish farmers in Mali [7]. We see here that witchoraft is used as a mechanism for social control to command cooperation rather than fan the flames of competition and individualism, because they least encourage collective societal efforts.

Differences are glaring when it comes to state politics. Greed and egoism are setting African elites, who emphasize individual happiness and competition, against each other and their masses with violent outcomes like wars. In July 2003, we conducted a focus group discussion with 40 women of between 28 to 65 years old from the southwest province of Cameroon as part of a wider research project on cultures and livelihoods. The women were asked to describe how they solve problems that affect their daily lives. They were further asked if these ways of solving life problems were still very effective today and the response was that they were eroding. When asked why, we got the following reasons: Schools teach individualistic values reminiscent of Western societies who introduced such schools in Africa during colonization and have done much to preserve them since then. The introduction of Western-style education, religious practices, mass media and governance structures reminds us that all that was African was replaced. These vehicles of Western civilization and individualism are firmly ingrained in the life of the population of SSA and are the net contributors to the region's impoverishment. The quality and quantity of African schools are never like their Western counterparts. Another reason is that economic pressures are relegating group behaviours to the background, especially in the cities where everybody is not farming and food self-sufficiency is a joke. Family relations and roles are changing as families spend time watching pop music and soap operas on television than tell folk tales and sing folk songs. Western religion is fast crushing traditional beliefs and practices that encourage a social security system based on kind, which fosters inter and intragenerational contracts for sustainability. Further research into the revival of these coping mechanisms is highly recommended.

\section{THE NEED TO WITHSTAND ECOLOGICAL, ECONOMIC AND SOCIAL SHOCKS}

As stated above, the unsustainable development strategies unquestionably adopted by SSA are making the region unable to withstand ecological, economic and social shocks. Concerted sectorial policies and actions that cut across the economic, social and ecological domains should be taken in a coherent and holistic manner to make Africa capable of self-sustenance. Environmental values and quality must benefit all in SSA. Natural resources are found in the backyard of the very poor in contemporary SSA, but their unsustainable exploitation by foreign companies has not benefited these poor [14]. For example, Cameroon has about 22 million ha of forests and timber accounts for about $6 \%$ of the country's GDP. But about 50 of the 90 logging permit holders, with the Lebanese group Hazim topping the list, have exceeded their exploitation quotas. Corrupt government officials coupled with the inherent inadequate human and financial capacities in Africa cannot control these powerful profitmaking giants. More than $68 \%$ of the people in the rural areas live in abject poverty and all of them rely heavily on forest resources. Decision makers in Cameroon need to realize that poverty and environmental degradation are bedfellows. Strong political awareness and will are needed to stop the unsustainable exploitation of natural resources that benefits the rich rather than everyone. Appropriate royalties should be imposed on the exploitation of the natural resources, while forest concessions should clearly state exploitation rates and exploiters should be strictly monitored. Exploitation should not only target more foreign currency earnings in the short term. The EU governments should be committed to buying wood from legal and sustainable sources through their voluntary mechanism to keep illegal timber out of the EU, as well as implement strong measures in their domestic markets. Resource availability is important to sustain an industrial base on the long term through carefully 


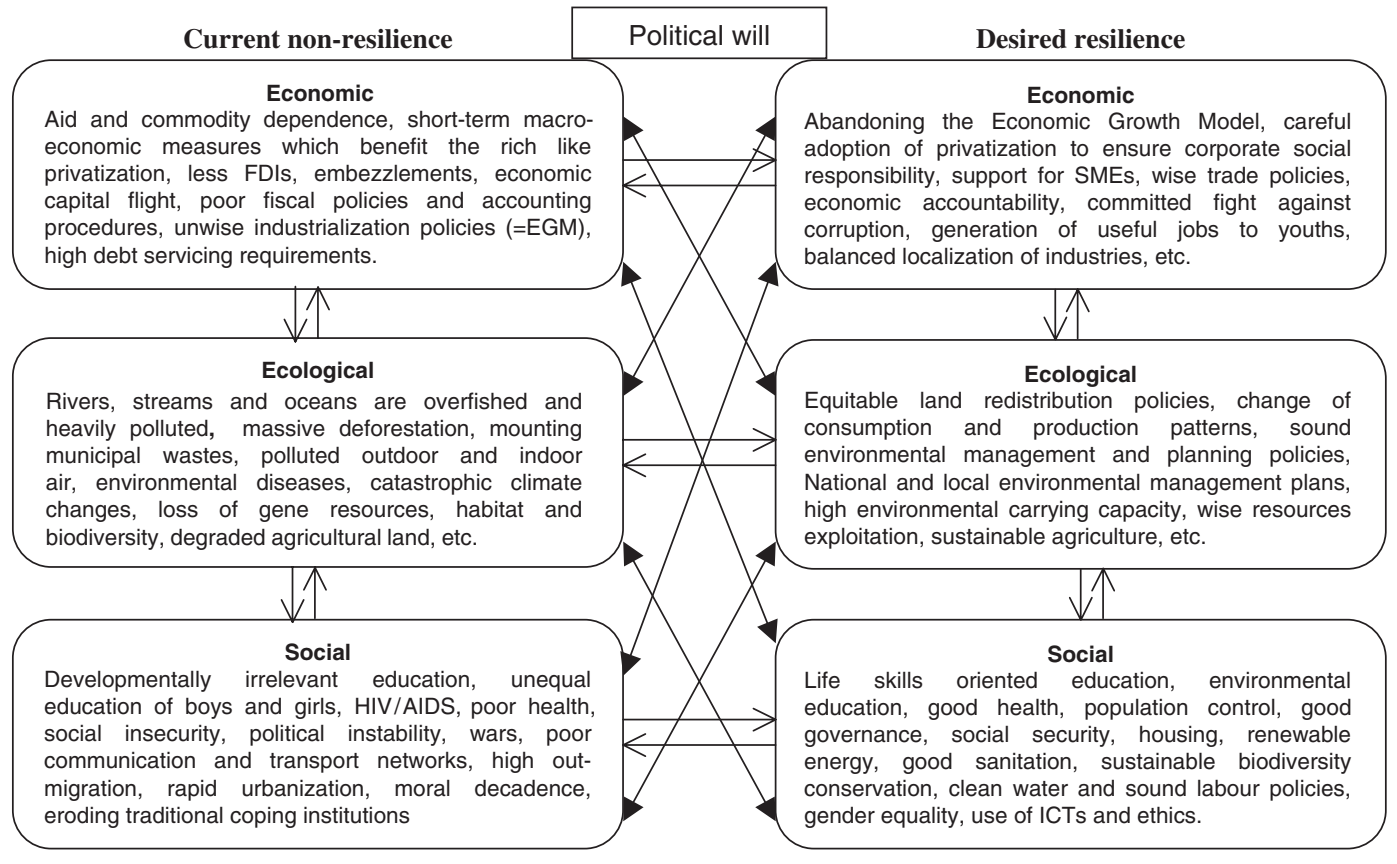

Figure 3: Economic, ecological and social resilience in SSA [2, 14]. Double arrows indicate that a supportive policy environment is necessary to move from non-resilience to resilience. Single arrows indicate that sectors are not isolated, they are interconnected and a holistic policy approach is needed. Such crosscutting policies should be coherent and actions oriented. Whatever the imagined future for Africa, without a good political will and local, national and international support the desired resilience will still not be achieved.

planned exploitation. Sound environmental management is a critical strategy for the well being of the rural poor [50]. Figure 3 shows that resilience in Africa is a matter for a supportive policy environment.

Sound and coherent redistributive economic policies should target those in extreme poverty. Africans should beware that environmental problems are associated with the way goods and services are produced and consumed. Overconsumption and overproduction reflect a wasteful and highly polluting lifestyle. Useful jobs for the youth and the support for SMEs will reduce unemployment and human degradation. Market interests should not overshadow societal happiness. However, this also means that the refugee crisis, which is fast becoming a portal for the drain of Africa's human capital, must be structured through an organized system of labour exportation and importation. This system promises a win-win scenario for both the exporting and importing countries as well as guarantees human freedom to live and work in any part of the world. Such human capital policies interconnect our fragmented world and ensure tolerance in diversity, and check human degradation through trafficking and exploitation. Patents and copyrights are good economic instruments and frameworks to protect traditional knowledge systems by improving the development, protection, ownership, management and use of regional intellectual property assets through better regulation and innovation ([51], p. 27).

While education plays a great role in sustainable development, the current educational practice has not made knowledge directly relevant to human development in SSA. An innovative resilience strategy in SSA requires critical long-term trends in every important area of community life through 
relationships amongst stakeholders that foster new agreements, initiatives and projects. Hence, education for sustainable development in Africa should focus on sustainability concepts and principles, so that Africans can develop a set of assets and concerns that can be measured using community sustainability indicators. Community-based indicators will enable social actors to understand and analyze (awareness) the state of their life support systems as against their actions. This awareness will push them to select and adopt innovative strategies and a platform for agreement on the appropriate action to take. This implies that education for sustainable development in SSA should also focus on creating cooperative action plans, policies, programmes and projects to be managed on a horizontal basis. African writers and playwrights have played a pivotal role in literary development and its implication for daily living. They bring to the forefront the communal virtues of African culture as against individualism in the Western countries, which has stirred a great desire in the people to amass wealth (materialism) even to the extent of stealing and plundering company and national assets. Acolytes of Ngugi, Achebe and Soyinka among others convey critical messages on the existential situation of poverty and the empowerment of the masses. Formal and informal education must complement each other to ensure that children, adults and managers should be socialized not only in schools and colleges but also in homes and the community.

A cautious adoption and adaptation of new technologies could simplify and facilitate the coordination of state financial activities, including taking out loans, paying them back and spending foreign capital. Hence, the level of corruption may diminish and bureaucracy may be reduced to the benefit of taxpayers.

\section{CONCLUSIONS}

SSA requires strategies for sustainable development, which must be initiated from within. This is because decades of development cooperation have not benefited the region in any significant way. The development strategies imposed on her serve the interests of donors. It can be concluded that the economic growth model imposed on Africa is largely responsible for her non-resilience. A sustainable economic growth model is required to allow the region to withstand internal and external shocks. This can only be achieved within an atmosphere of peace, good governance and mutual cooperation. It is the duty and call of every African to generate an awareness of the current malaises of the region with a view to actively contribute to solving them. Priority in research into these problems will require the use of global knowledge to generate new local knowledge on how to revitalize the traditional coping mechanisms of Africans. However, this requires freedom of knowledge or the propensity to fall back onto the traditional knowledge societies of the past that were killed with the advent of dictatorships. South-south NGO networking remains the vital tool to accomplish this mission, since they are grassroots organizations that reflect the best interest of the ordinary African.

\section{REFERENCES}

[1] United Nations Development Programme (UNDP), Human Development Report 2004: Cultural Liberty in Today's Diverse World, UNDP: New York, 2004.

[2] Eyong, C., Poverty eradication and sustainable development in Cameroon, Journal of Sustainable Development in Africa, 5(2) pp. 30-58, 2003.

[3] United Nations Development Programme (UNDP), Deepening democracy in a fragmented world. Human Development Report, Oxford University Press: New York, pp. 13-49, 2002.

[4] United Nations Development Programme (UNDP), Human Development Report 2003 Millenium Development Goals: A Compact Among Nations to End Human Poverty, UNDP: New York, 2003. 
[5] Rabinow, P., Representations are social facts: modernity and post modernity in anthropology. Writing Culture: The Politics of Ethnography, ed. J. Clifford \& G. Marcus, University of California Press: Berkeley, CA, pp. 234-262, 1986.

[6] Eyong, C.T., Mufuaya, M., \& Foy, I.I., Literature and Culture - The Sustainability Connection from an African Perspective, Regional Sustainable Development Review: Africa, from Encyclopedia of Life Support Systems (EOLSS), Developed under the auspices of the UNESCO, Eolss Publishers: Oxford, UK, http://www.eolss.net, 2004.

[7] Crewe, E. \& Harrison, E., Whose development? An Ethnography of Aid, Zed Books: London, pp. 30-48, February, 1999.

[8] Eriksen, T.H., Class, Nation and Identity: The Anthropology of Political Movements, Pluto Press: London, April 2003.

[9] World Bank Group (2003), Culture and Poverty: Learning and Research at the World Bank, World Bank Group: Washington, DC, September 2003.

[10] Brown, L.R., Building a Sustainable Society, W. W. Norton \& Co, Inc.: New York, 1981.

[11] World Commission on Environment and Development Report, Our Common Future, Oxford University Press: Oxford, UK, pp. 1-8, 1987.

[12] Kates, R.W. \& Leiserowitz, A.A., What is sustainable development? Goals, indicators, values and practice. Environment, 47(3), pp. 10-21, 2005.

[13] Weaver, H., Rock, M. \& Kusterer, K., Achieving Broad-Based Sustainable Development: Governance, Environment and Growth with Equity, Kumarin Press: Connecticut, USA, pp. 214, 1997.

[14] Boon, E. \& Eyong, C.T., History and Civilisations: Impacts on Sustainable Development in Africa, Regional Sustainable Development Review: Africa, from Encyclopedia of Life Support Systems (EOLSS), Developed under the auspices of the UNESCO, Eolss Publishers: Oxford, UK, http://www.eolss.net, 2005.

[15] Green, R.L., The Empire of Ghana: A First Book, Franklin Watts: New York, 1998.

[16] Ranger, T., The invention of tradition in colonial Africa. The Invention of Tradition, eds. E. Hobsbawm, \& T. Ranger, Cambridge University Press: Cambridge, 1983.

[17] Mamdani, M., Citizen and Subject: Contemporary Africa and the Legacy of Late Colonialism, Princeton University Press: Princeton, 1996.

[18] Ascher, W., Understanding why governments in developing countries waste natural resources. Environment, pp. 8-18, March 2000.

[19] Vubo, Y.E., The discourse and politics of indigenous/minority people's rights in some metropolitan areas of Comeroon. Journal of Applied Social Sciences, 1(1), pp. 25-41, 1998.

[20] United Nations Conference on Trade and Development (UNCTAD), Trade Performance and Commodity Dependence, UNCTAD secretariat: New York and Geneva, 2003.

[21] Nath, B., Environmental education: the Johannesburg Summit and beyond. Making Globalisation Sustainable? The Johannesburg Summit on Sustainable Development and Beyond, ed. E. Nierynck et al., VUB Press: Brussels, pp. 173-190, 2003.

[22] United Nations Conference on Trade and Development (UNCTAD), The Least Developed Countries Report (2004): Linking International Trade with Poverty Reduction, United Nations Publications: Geneva, 2004.

[23] Oxfam International, Growth with equity briefing paper of Oxfam Community Aid Abroad, Fitzroy, Victoria, Australia, 2000.

[24] Avery, D.T., WTO cotton ruling would benefit U.S. farmers, consumers and help poor nations' economies, eTaiwan News.com, opinion page, 20 June 2004, http://www.etaiwannews.com/ opinion/2004/06/20/1087702675.htm 
[25] ActionAid, The Cotton Dispute: A Victory for the World's Poor Farmers, ActionAid Press: London, 2004.

[26] World Bank, World Development Indicators (2004), The World Bank: Washington, DC, April, 2004.

[27] Boyce, J.K. \& Ndikumana, L., Africa's debt: who owes whom? Political Economy Research Institute, University of Massachusetts, Working Paper series, no. 48, 2002.

[28] Lancaster, C., Aid to Africa: So Much To Do, So Little Done, University of Chicago Press: Chicago, IL, 1999.

[29] Boyce J.K. \& Ndikumana L., Is Africa a net creditor? new estimates of capital flight from severely indebted sub-Saharan African countries, Political economy research institute, University of Massachusetts, Working Paper series, no. 5, 2000.

[30] Fides Service, Leaving Africa for jobs in the West, July 5, 2006, http://www.xaviermissionaries. org/M_Life/NewsArchive/AfricaNews/Afr_LeavingJobs.htm

[31] Turner, M. \& Hulme, D., Governance, Administration and Development: Making the State Work, Macmillan Press Ltd.: Hong Kong, 1997.

[32] Caldwell, J. \& Caldwell, P., The Fertility Transition in Sub-Saharan Africa. Department of Social Development and Human Sciences Research Council: Pretoria, South Africa, October, 2002.

[33] Nana-Fabu, Stella, High fertility and development in Cameroon. Journal of Social Development in Africa, 16(1), pp. 23-42, 2001.

[34] United Nations Habitats Programme (UNHABITATS), Press Briefing on 2003 Human Settlements Report, EarthScan: UK, September, 2003.

[35] Eyong, C.T., Indigenous knowledge systems (IKS) in Africa and their relevance for sustainable development: case study of Central Africa. Paper presented at the International Conference on Indigenous Knowledge Systems (IKS) in Africa and their Relevance for Sustainable Development, Human Ecology Department, Vrije Universiteit Brussel, Belgium, 21-23 November 2005.

[36] Zanganeh, L.A., Timbuktu was Paris of Islamic intellectuals. New York Times, 25 April 2004, http://www.azcentral.com/arizonarepublic/news/articles/0425timbuktu251.html

[37] Mkandawire, T., Can Africa have developmental states? Ordering the International: History, Change and Transformation, eds. W. Brown, S. Bromley \& S. Athreye Mi, Pluto Press in association with The Open University Press: London/Ann Arbor, pp. 337-375, 2004.

[38] Carbon emissions: a global overview in 10 Points. The Globalist, 20 August 2003, http://www. theglobalist.com/DBWeb/printStoryId.aspx ?StoryId $=3285$

[39] United Nations Development Programme (UNDP), Poverty/Economy Programme: Country Profile, Botswana, http://www.unbotswana.org.bw/undp/poverty_country.html, retrieved on 30 November 2005.

[40] United Nations Commission on Trade and Development (UNCTAD) and International Centre for Trade and Sustainable Development (ICTSD), Intellectual Property Rights and Sustainable Development, policy discussion paper, August 2003.

[41] Nkrumah, G., Africa, aid and sanctions: a tall order. Foreign Policy in Focus, 12 July 2002.

[42] Labonte, R., Schrecker, D., Sanders, D. \& Meeus, W., Fatal Indifference: The G8, Africa and Global Health, International Research and Development Center: Canada, 2004.

[43] International Association of Universities (IAU), The Ubuntu Declaration seeks global alliance for sustainable development, Reference no. PAA_C1/10.3.1, p. 4, 2002.

[44] Boulding, K.E., Ecology of coming spaceship earth. Valuing the Earth, eds. H.E. Daly \& K.N. Townsend, MIT Press: Cambridge, pp. 297-309, 1996. 
[45] Begossi, A., Knowledge on the use of natural resources: contributions to local management. Research in Human Ecology: An Interdisciplinary Overview, eds. Luc Hens et al., VUB Press: Belgium, pp. 39-51, 1998.

[46] Cernea, M.M \& Schmidt-Soltau, K., Biodiversity Conservation and Poverty Risks: Is Population Resettlement the Solution? Lit Verlag: Hamburg/London, 2005, in print.

[47] Hastrup, Kirsten., A Passage to Anthropology: Between Experience and Theory, Routledge: London/New York, 1995.

[48] Watson, C.W., Being There: Fieldwork in Anthropology, Pluto Press: London, 1999.

[49] Kottak, P., Anthropology: The Exploration of Human Diversity, 5th edn, McGraw-Hill: USA, 1991.

[50] Eyong, C.T. \& Mbuagbo, O.T., Assessment of the hygiene and sanitation campaign in Cameroon. Journal of Environment, Sustainability and Development, 4(4), pp. 391-402, 2002.

[51] Intellectual property. Developments, The International Development Magazine, 25, 1st Quarter, 2004. 